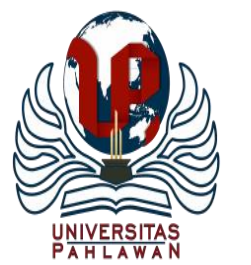

Edukatif : Jurnal Ilmu Pendidikan Volume 3 Nomor 5 Tahun 2021 Halm 2760 - 2768

EDUKATIF: JURNAL ILMU PENDIDIKAN

Research \& Learning in Education

https://edukatif.org/index.php/edukatif/index

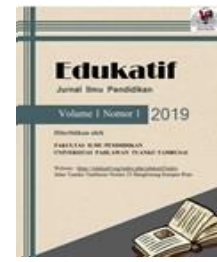

\title{
Efektivitas Media Powerpoint dalam Pembelajaran Materi Luas Daerah Segitiga untuk Meningkatkan Minat Belajar Peserta Didik di Sekolah Dasar
}

\author{
Fikri Alamsyah Nugraha ${ }^{1 凶}$, Epon Nur'aeni², Yusuf Suryana ${ }^{3}$, Muhammad Rijal Wahid M. ${ }^{4}$ \\ Universitas Pendidikan Indonesia, Indonesia, $2,3,4$ \\ E-mail : $\underline{\text { fikri.alamsyah23@upi.edu }}^{1}, \underline{\text { nuraeni @ upi.edu }}^{2}, \underline{\text { rijalmuharram@ @upi.edu }}^{3}$, yusufsuryana@upi.edu ${ }^{4}$
}

\begin{abstract}
Abstrak
Penelitian ini bertujuan untuk meningkatkan minat belajar peserta didik dalam pembelajaran luas daerah segitiga dengan menggunakan media powerpoint di Sekolah Dasar. Karena peneliti menemukan kurangnya minat peserta didik ketika menggunakan media pembelajaran konvensional di Sekolah Dasar. Media Powerpoint merupakan media yang mudah serta banyak digunakan oleh guru. Metode penelitian yang digunakan adalah metode Quasi Experiment dengan populasi Kelas IV di SDN 1 Sukamaju sebanyak 56 peserta didik dan sampel ditentukan secara Purvosive Sampling (Sampel Bertujuan) yaitu Kelas IVA sebanyak 28 Peserta didik sebagai kelas eksperimen dan Kelas IVB sebanyak 28 Peserta didik sebagai kelas kontrol. Instrumen penelitian yang digunakan adalah Angket minat belajar dengan jumlah 8 nomor item. Teknik analisis menggunakan Microsoft Office Excel 2010 dan SPSS 16.0. Hasil penelitian ini setelah Uji hipotesis dengan Uji $\mathrm{T}$ menghasilkan $t_{\text {hitung }}=2,141$ dengan taraf signifikansi $5 \%$ atau 0,05 menghasilkan $t_{\text {tabel }}=1,673$. Dengan demikian, penggunaan media powerpoint terbukti efektif dalam pembelajaran materi luas daerah segitiga untuk meningkatkan minat belajar peserta didik Kelas IV Sekolah Dasar.
\end{abstract}

Kata Kunci: Minat Belajar, Powerpoint, Matematika, Sekolah Dasar.

\begin{abstract}
The research purpose to increase students' interest learning in triangular area, the using powerpoint media in elementary schools. Because the researchers found a lack of interest in students when using conventional learning media in elementary schools. Powerpoint media is an easy medium and is widely used by teachers. The research method used is the Quasi Experiment method with a population of Class IV at SDN 1 Sukamaju as many as 56 students and the sample is determined by Purvosive Sampling, in Class IVA as many as 28 students as the Experiment class and in Class IVB as many as 28 students as the control class. The research instrument used was a learning interest questionnaire with a total of 8 item numbers. The analysis technique uses Microsoft Office Excel 2010 and SPSS 16. O. The results of this study after testing the hypothesis with the $T$ test resulted in $t_{\text {count }}=2.141$ with a significance level of $5 \%$ or 0.05 resulting in $t_{\text {table }}=1.673$. Thus, the use of powerpoint learning media has proven to be effective in learning the material for the area of triangles to increase the learning interest of Class IV Elementary School students.
\end{abstract}

Keywords: Learning Interest, Powerpoint, Mathematics, Elementary School.

Copyright (c) 2021 Fikri Alamsyah Nugraha, Epon Nur'aeni, Yusuf Suryana,

Muhammad Rijal Wahid M

$\triangle$ Corresponding author

Email : fikri.alamsyah23@upi.edu

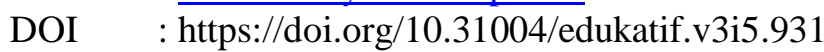

ISSN 2656-8063 (Media Cetak)

ISSN 2656-8071 (Media Online) 
2761 Efektivitas Media Powerpoint dalam Pembelajaran Materi Luas Daerah Segitiga untuk Meningkatkan Minat Belajar Peserta Didik di Sekolah Dasar - Fikri Alamsyah Nugraha, Epon Nur'aeni, Yusuf Suryana, Muhammad Rijal Wahid M

DOI: https://doi.org/10.31004/edukatif.v3i5.931

\section{PENDAHULUAN}

Pendidikan merupakan upaya dan proses pendewasaan individu secara sadar dalam pembelajaran dengan hasil perubahan perilaku sesuai tujuan yang ingin dicapai. Hal ini sejalan dengan tujuan pendidikan yaitu mendewasakan individu ke arah yang lebih baik. Oleh karena itu, pendidikan menjadi prioritas utama dalam membentuk manusia menjadi atau mencapai kedewasaan. Dalam mencapai tujuan pendidikan tersebut perlu ditempuh oleh setiap individu tersebut, salah satunya mengikuti pendidikan formal. Dalam UU Nomor 20 Tahun 2003 tentang sistem pendidikan nasional disebutkan bahwa lembaga pendidikan formal adalah jalur pendidikan yang terstruktur dan berjenjang yang terdiri atas pendidikan dasar, pendidikan menengah dan pendidikan tinggi.

Pada jenjang sekolah dasar terdapat berbagai macam mata pelajaran, salah satunya matematika. Hal tersebut sebagaimana diungkapkan oleh (Sirait, 2016) bahwa Matematika merupakan kebutuhan bagi kita semua, karena matematika merupakan pelajaran yang selalu berkaitan dengan keadaan kehidupan sehari-hari. Dengan melihat pentingnya matematika maka seharusnya matematika menjadi pelajaran yang disenangi sehingga peserta didik akan berminat untuk mempelajari matematika. Oleh karena itu, perlu perancangan khusus untuk menunjang peserta didik supaya lebih bersemangat dalam mempelajari matematika. Pendapat lain menurut (Basa \& Hudaidah, 2021) menyebutkan bahwa pembelajaran matematika yang kurang dalam melibatkan peserta didik untuk aktif akan menyebabkan peserta didik tidak dapat menggunakan secara optimal kemampuan matematikanya dalam menyelesaikan permasalahan matematika. Dengan demikian, perlu sebuah hal yang dapat melibatkan peserta didik untuk aktif dalam proses pembelajaran.

Geometri merupakan salah satu cabang dari matematika yang sudah sejak lama dipelajari. Dari jenjang Sekolah Dasar (SD), geometri sudah mulai dipelajari oleh peserta didik, bahkan sejak kelas rendah (Nuraeni, E, L \& Rijal, M, W, 2017). Oleh karena itu, media pembelajaran yang interaktif dapat mengajarkan kepada peserta didik di kelas sehingga proses pembelajaran dapat berjalan lebih kondusif dan dapat meningkatkan minat belajar peserta didik sehingga penguasaan konsep yang diajarkan mudah dipahami. Berhubungan dengan itu (Mufti et al., 2020) menuturkan bahwa penggunaan media atau alat peraga yang dapat membantu siswa memahami konsep geometri sehingga materi yang disampaikan bersifat abstrak dan menimbulkan kejenuhan bagi siswa dan sama hal tersebut disamapaikan oleh (Siregar, 2017) bahwa guru matematika memiliki tugas yang besar untuk membangkitkan dan mempertahankan minat peserta didik, mengingat pembelajaran matematika bersifat hiearki dari yang mudah ke sukar dan dari sederhana ke kompleks. Disamping itu, pembelajaran matematika di Sekolah Dasar (SD) yang diciptakan guru dapat membuat peserta didik berpandangan bahwa matematika merupakan kegiatan yang mengasyikan.

Minat belajar peserta didik perlu ditumbuhkan dalam pembelajaran, agar siswa tersebut mempunyai ketertarikan terhadap materi yang diajarkan. Sejalan dengan yang disampaikan oleh (Yunitasari \& Hanifah, 2020) bahwa minat belajar juga merupakan faktor pendorong untuk siswa dalam belajar yang didasari atas ketertarikan atau juga rasa senang keinginan iswa itu untuk belajar. Dalam hal minat belajar pun (Harahap et al., 2021) menyebutkan bahwa minat mempunyai peranan yang sangat penting dalam belajar. Dalam (Fauziah et al., 2017) pun menuturkan minat peserta didik juga membutuhkan dorongan atau gerakan untuk mencapai tujuannya atau cita-citanya. Minat belajar peserta didik pun perlu dorongan supaya bersifat aktif. Berkaitan dengan hal tersebut (I. Lestari, 2013) mengungkapkan bahwa Belajar bersifat aktif, siswa sebagai peserta didik tidak akan mampu merubah perilaku jika ia tidak aktif mengikuti setiap proses yang berlangsung. Efektivitas pembelajaran melekat pada aktivitas belajar dan partisipasi siswa. Untuk dapat bersikap aktif dibutuhkan pula faktor penggerak yang secara langsung memberi dorongan pada siswa untuk bertindak. Faktor pendorong yang dimaksud adalah minat belajar. Dengan tumbuhnya minat belajar, siswa akan 
2762 Efektivitas Media Powerpoint dalam Pembelajaran Materi Luas Daerah Segitiga untuk Meningkatkan Minat Belajar Peserta Didik di Sekolah Dasar - Fikri Alamsyah Nugraha, Epon Nur'aeni, Yusuf Suryana, Muhammad Rijal Wahid M

DOI: https://doi.org/10.31004/edukatif.v3i5.931

berusaha menemukan momen yang tepat dan kondisi yang menarik untuk turut larut dalam proses pembelajaran.

Dalam (Yuza, 2018) Pengajaran konsep luas daerah segitiga sebenarnya merupakan hal yang mudah. Selama ini, guru biasanya langsung memberikan drill rumus perhitungan luas bangun datar ini. Dalam hal pemahaman konsep pun (Mustajin et al., 2019) mengungkapkan bahwa kenyataannya di SDN Pahlawan, saat proses pembelajaran berlangsung pada mata pelajaran matematika tentang luas bangun datar segitiga penggunaan media masih belum bervariasi sehingga penyampaian materi atau konsep kurang tersampaikan dengan maksimal. Oleh karena itu, perlu adanya variasi dalam pembelajaran supaya pemahaman konsep peserta didik dapat dengan mudah memahaminya.

Variasi pembelajaran seharusnya dilakukan dengan menggunakan media pembelajaran yang mudah digunakan oleh guru. Media dalam prespektif pendidikan merupakan instrumen yang sangat strategis dalam ikut menentukan keberhasilan proses belajar mengajar. Sebab kegunaannya secara langsung dapat memberikan dinamika tersendiri terhadap peserta didik. Oleh karena itu, media pembelajaran mengartikan instrumen harus dikemas dengan sematang dan sejalan dengan zaman. Ditambah lagi dengan perkembangan zaman yang pesat, peserta didik bisa jadi lebih berminat ketika diberikan media pembelajaran yang menarik sekaligus menghibur. Sejalan dengan (Nurseto, 2012) menjelaskan bahwa Sesuai dengan kemajuan Teknologi Pendidikan (Educational Technology), maupun Teknologi Pembelajaran (Instructional Technology) menuntut digunakannya berbagai media pembelajaran (instructional media) serta peralatan-peralatan yang semakin canggih (sophisticated). Hal tersebut pun sesuai dengan yang diungkapkan oleh (Asnawir, 2002) mengemukakan bahwa media pembelajaran adalah Alat, metode, dan teknik yang digunakan dalam rangka lebih mengefektifkan komunikasi dan interaksi antara guru dalam proses pendidikan dan pengajaran di sekolah. Salah satu media pembelajaran yang mudah digunakan adalah media pembelajaran powerpoint. Menurut (Annisa \& Simbolon, 2018) bahwa media pembelajaran powerpoint merupakan media pembelajaran yang mengandung unsur teks, suara, gambar, dan video. Sama halnya dengan yang disampaikan oleh (Roblyer \& Doering, 2014) dalam penelitian (Chou et al., 2015) bahwa elemen multimedia seperti video, audio dan dokumen hyperlink yang terdapat pada powerpoint dapat secara efisien dalam menyajikan materi pembelajaran sehinga dapat menarik perhatian peserta didik dan merangsang proses berpikir mereka. Oleh karena itu, Guru pun harus mampu membuat media pembelajaran dengan sematang mungkin sehingga peserta didik dapat dengan mudah memahami materi yang diajarkannya. Sekaitan dengan hal tersebut (Puspita et al., 2020) mengungkapkan media pembelajaran powerpoint interaktif sangat diperlukan untuk meningkatkan hasil belajar siswa. Dari media tersebut siswa dapat lebih memahami materi secara mendalam melalui gambar atau video yang telah disajikan dalam media, selain itu siswa dapat lebih mengetahui teknologi berbasis komputer sebagai pengetahuan mereka dalam belajar.

Berdasarkan hasil studi pendahuluan yang diperoleh, beberapa peserta didik di kelas IV SDN 1 Sukamaju memiliki minat belajar yang kurang maksimal salah satunya dalam pembelajaran matematika. Hal tersebut ditandai dengan minat belajar yang masih sulit didapatkan oleh peserta didik. Dalam kegiatan analisis hal tersebut, beberapa peserta didik memiliki minat yang masih beragam, dalam artian terdapat beberapa peserta didik yang masih kesulitan tersebut berdampak dalam memahami konsep yang diajarkan. Dalam hal ini, peneliti menyakini bahwa di kelas tersebut terdapat penggunaan media pembelajaran yang masih konvensional atau belum dikembangkan. Keyakinan peneliti ini kemudian terkonfirmasi melalui studi pendahuluan dengan kegiatan wawancara kepada guru kelas IV SDN 1 Sukamaju. Dengan demikian, dari hasil studi pendahuluan tersebut, peneliti tertarik untuk melihat minat belajar peserta didik dengan menggunakan media pembelajaran.

Banyak penelitian yang telah dilakukan oleh para peneliti bidang pendidikan perihal minat belajar dengan menggunakan media pembelajaran powerpoint. Misalnya penelitian yang dilakukan oleh (Elpira \& 
2763 Efektivitas Media Powerpoint dalam Pembelajaran Materi Luas Daerah Segitiga untuk Meningkatkan Minat Belajar Peserta Didik di Sekolah Dasar - Fikri Alamsyah Nugraha, Epon Nur'aeni, Yusuf Suryana, Muhammad Rijal Wahid M

DOI: https://doi.org/10.31004/edukatif.v3i5.931

Ghufron, 2015) perihal pengaruh penggunaan media powerpoint terhadap minat dan hasil belajar ipa siswa kelas IV SD yang menyimpulkan bahwa penggunaan media Powerpoint IPA terbukti berpengaruh terhadap minat dan hasil belajar. Penelitian terkait juga telah dilaksanakan oleh (Flora Siagian, 2015) perihal pengaruh minat dan kebiasaan belajar siswa terhadap prestasi belajar matematika, yang menyimpulkan bahwa . Namun, masih belum banyak dijumpai penelitian yang dilakukan khusus untuk penggunaan media pembelajaran powerpoint di Sekolah Dasar, terkhusus pada penelitian yang membahas minat belajar peserta didik Sekolah Dasar dalam Pembelajaran luas daerah segitiga.

Berdasarkan teori-teori diatas harapan peneliti untuk hasil penelitian ini, para guru dapat menggunakan media powerpoint dalam pembelajarannya. Karena selain berbau teknologi, media powerpoint pun dapat serta mudah digunakan oleh guru. Dalam media powerpoint terdapat animasi yang dapat meningkatkan minat belajar serta on point sehingga memudahkan peserta didik dalam memahami materi yang disampaikan. Sejalan dengan itu (Chrismawati et al., 2021) dalam Suryani et al. (2018) powerpoint merupakan perangkat lunak pengolah presentasi yang memuat objek teks, grafik, video, suara, dan objek-objek yang diposisikan dalam beberapa halaman atau disebut "slide".

Tujuan yang ingin dicapai dari hasil penelitian ini dibagi menjadi tujuan umum dan tujuan khusus. Tujuan umumnya peneliti mengharapkan dalam hal konkret perihal minat belajar dalam pembelajaran luas daerah segitiga dengan menggunakan media powerpoint di Kelas IV Sekolah Dasar dapat meningkatkan minat belajar peserta didik tersebut sehingga dalam efektivitas pembelajarannya pun dapat berjalan dengan mudah. Sedangkan tujuan khusus penelitian ini adalah untuk mengetahui: 1) Minat belajar peserta didik terhadap pembelajaran luas daerah segitiga tanpa media pembelajaran powerpoint di Kelas IV Sekolah Dasar, 2) Minat belajar peserta didik terhadap pembelajaran luas daerah segitiga dengan menggunakan media pembelajaran powerpoint di Kelas IV Sekolah Dasar dan 3) Efektivitas penggunaan media pembelajaran powerpoint di Kelas IV Sekolah Dasar terhadap minat belajar peserta didik pada pembelajaran luas daerah segitiga.

\section{METODE PENELITIAN}

Penelitian ini menggunakan metode eksperimen dengan pendekatan kuantitatif dalam bentuk desain Quasi Eksperiment. Penelitian ini dimulai dengan permasalahan, yang terdiri dari latar belakang, identifikasi masalah kemudian rumusan masalah. Permasalahan tersebut selanjutnya dijelaskan dan dibahas melalui teori.

Populasi dalam penelitian ini merupakan peserta didik kelas IV Sekolah dasar di Wilayah Kota Tasikmalaya. Sistem pengambilan sampelnya menggunakan teknik Purposive Sampling. Dalam (E. K. Lestari \& Yudhanegara, 2017) menyebutkan bahwa teknik Purposive Sampling adalah teknik penentuan sampel dengan pertimbangan tertentu. Dengan demikian, Sampel dalam penelitian ini diambil dua rombel dari kelas IV di SDN 1 Sukamaju. Kelas IVA dengan jumlah 28 peserta didik sebagai kelas eksperimen dengan pembelajaran menggunakan media powerpoint dan Kelas IVB dengan jumlah 28 peserta didik sebagai kelas kontrol dengan pembelajaran tanpa menggunakan media powerpoint.

Teknik pengumpulan data dalam penelitian menggunakan angket minat belajar yang mana digunakan untuk mendapatkan data skor angket minat belajar peserta didik kelas IV SDN 1 Sukamaju. Adapun angket minat belajar tersebut kemudian di expert judgement yaitu memvalidasi angket tersebut kepada ahli bahasa dan ahli statistik. Sehingga setelah diberikan expert judgement angket tersebut pun dirancang semaksimal mungkin yang kemudian di uji cobakan terlebih dahulu kepada peserta didik kelas IV untuk mendapatkan validitas konstruk terhadap 15 nomor item pada angket. Setelah mendapatkan data skor uji coba, dimasukkan kedalam software SPSS 16.0 untuk menganalisis nomor item mana saja yang valid digunakan untuk penelitian hasilnya terdapat 7 nomor item yang valid dan 8 nomor item tidak valid. Setelah itu, dengan 7 nomor item yang valid langkah terakhir adalah realibilitas yang berguna untuk meyakinkan bahwa data yang diperoleh 
2764 Efektivitas Media Powerpoint dalam Pembelajaran Materi Luas Daerah Segitiga untuk Meningkatkan Minat Belajar Peserta Didik di Sekolah Dasar - Fikri Alamsyah Nugraha, Epon Nur'aeni, Yusuf Suryana,

Muhammad Rijal Wahid M

DOI: https://doi.org/10.31004/edukatif.v3i5.931

adalah nyata. Selanjutnya dalam teknik analisis data skor hasil angket minat belajar tersebut kemudian diolah dengan teknik analisis uji normalitas menggunakan uji liliefors, uji homogenitas dan uji-T untuk pengambilan kesimpulannya. untuk mempermudah peneliti dalam proses analisis data, peneliti menggunakan Software Microsoft Excel dan SPSS versi 16.0.

\section{HASIL DAN PEMBAHASAN PENELITIAN}

Pada tabel 1 dijelaskan perihal kelas kontrol yang mana didalam pembelajarannya tidak diberikan media pembelajaran powerpoint menghasilkan data berikut:

Tabel 1. Ketentuan Kategori Minat Belajar Peserta Didik Tanpa Menggunakan Media Pembelajaran Powerpoint (Kelas Kontrol)

\begin{tabular}{lc}
\multicolumn{1}{c}{ Persyaratan } & $\begin{array}{c}\text { Kategori } \\
\text { Minat Belajar }\end{array}$ \\
\hline$>$ Rata-rata skor minat + Standar Deviasi & Tinggi \\
$>19,50+2,15$ & \\
$>\mathbf{2 1 , 6 5}$ & \\
\hline$=($ Rata-rata skor minat - Standar Deviasi) s.d. & \\
(Rata-rata skor minat + Standar Deviasi) & Sedang \\
$=(19,50$ - 2,15) s.d. $(19,50+2,15)$ & \\
$=\mathbf{1 7 , 3 5}$ s.d. 21,65 & \\
\hline$<$ Rata-rata skor minat - Standar Deviasi & Rendah \\
$<19,50-2,15$ & \\
$<\mathbf{1 7 , 3 5}$ & \\
\hline
\end{tabular}

Dari tabel tersebut dapat dilihat bahwa minat belajar peserta didik dalam pembelajaran luas daerah segitiga dalam kelas kontrol dikatakan tinggi jika skor angket minat belajar peserta didiknya lebih besar dari 21,65. Sedangkan dikatakan minat belajarnya rendah jika skor angket minat belaja peserta didikrnya lebih kecil dari 17,35. Dan dikatakan sedang jika skor angket minat belajar peserta didiknya diantara keduanya atau dengan kata lain 17,35 sampai dengan 21,65.

Dengan demikian dapat ditarik tabel 2 berupa distribusi frekuensi data minat belajar peserta didik dalam pembelajaran luas daerah segitiga dalam kelas kontrol sebagai berikut:

Tabel 2. Tabel Distribusi Frekuensi Data Minat Belajar Peserta Didik Tanpa Menggunakan Media Pembelajaran Powerpoint (Kelas Kontrol)

\begin{tabular}{ccccc}
\hline Skor Minat & Frekuensi & $\mathbf{F}_{\text {relatif }}$ & $\mathbf{F}_{\text {komulatif }}$ & Kategori \\
\hline $16-17$ & 7 & $25 \%$ & $25 \%$ & Rendah \\
\hline $18-21$ & 15 & $54 \%$ & $79 \%$ & Sedang \\
\hline $22-23$ & 6 & $21 \%$ & $100 \%$ & Tinggi \\
\hline
\end{tabular}

Dari tabel distribusi frekuensi diatas dapat diketauhi bahwa dari 7 nomor item yang terdapat dalam angket minat belajar peserta didik yang diberikan pada 28 peserta didik di kelas kontrol diperoleh skor terbanyak adalah 18 - 21 yaitu dengan 15 peserta didik atau sekitar 54\% dari total keseluruhan peserta didik dalam kelas kontrol dan masuk kedalam kategori sedang, artinya peserta didik senang dalam proses pembelajaran, ketertarikan terhadap pembelajaran dan bersemangat dalam pembelajaran luas daerah segitiga. Selanjutnya skor 16 - 17 yang termasuk dalam kategori rendah diperoleh oleh 7 peserta didik atau $25 \%$ dari total keseluruhan peserta didik kelas kontrol dalam artian peserta didik tersebut hanya memenuhi sekitar satu indikator minat belajar atau bahkan tidak memenuhi indikator angket minat belajar. Dan skor $22-23$ yang termasuk dalam kategori tinggi diperoleh oleh 6 peserta didik atau 21\% dari total keseluruhan peserta didik di 
2765 Efektivitas Media Powerpoint dalam Pembelajaran Materi Luas Daerah Segitiga untuk Meningkatkan Minat Belajar Peserta Didik di Sekolah Dasar - Fikri Alamsyah Nugraha, Epon Nur'aeni, Yusuf Suryana,

Muhammad Rijal Wahid M

DOI: https://doi.org/10.31004/edukatif.v3i5.931

kelas kontrol dalam artian memenuhi hampir semua indikator atau memenuhi semua inndikator dalam angeket minat belajar tersebut.

Sedangkan pada tabel 3 kelas eksprimen yang mana didalam pembelajarannya diberikan media pembelajaran powerpoint menghasilkan data berikut:

Tabel 3. Ketentuan Kategori Minat Belajar Peserta Didik Menggunakan Media Pembelajaran Powerpoint (Kelas Eksperimen)

\begin{tabular}{lc}
\multicolumn{1}{c}{ Persyaratan } & $\begin{array}{c}\text { Kategori } \\
\text { Minat Belajar }\end{array}$ \\
\hline$>$ Rata-rata skor minat + Standar Deviasi & Tinggi \\
$>22,25+2,78$ & \\
$>\mathbf{2 5 , 0 3}$ & \\
\hline$=($ Rata-rata skor minat - Standar Deviasi) s.d. & \\
(Rata-rata skor minat + Standar Deviasi) & Sedang \\
$=(22,25-2,78)$ s.d. $(22,25+2,78)$ & \\
$=\mathbf{1 9 , 4 7}$ s.d. $\mathbf{2 5 . 0 3}$ & \\
\hline$<$ Rata-rata skor minat - Standar Deviasi & Rendah \\
$<22,25-2,78$ & \\
$<\mathbf{1 9 , 4 7}$ & \\
\hline
\end{tabular}

Dari tabel tersebut dapat dilihat bahwa minat belajar peserta didik dalam pembelajaran luas daerah segitiga dalam kelas kontrol dikatakan tinggi jika skor angket minat belajar peserta didiknya lebih besar dari 25,03. Sedangkan dikatakan minat belajarnya rendah jika skor angket minat belaja peserta didikrnya lebih kecil dari 19,47. Dan dikatakan sedang jika skor angket minat belajar peserta didiknya diantara keduanya atau dengan kata lain 19,47 sampai dengan 25,03.

Dengan demikian dapat ditarik tabel 4 berupa distribusi frekuensi data minat belajar peserta didik dalam pembelajaran luas daerah segitiga dalam kelas eksperimen sebagai berikut:

Tabel 4. Tabel Distribusi Frekuensi Data Minat Belajar Peserta Didik Menggunakan Media Pembelajaran Powerpoint (Kelas Eksperimen)

\begin{tabular}{ccccc}
\hline Skor Minat & Frekuensi & $\mathbf{F}_{\text {relatif }}$ & $\mathbf{F}_{\text {komulatif }}$ & Kategori \\
\hline $16-19$ & 4 & $14 \%$ & $14 \%$ & Rendah \\
\hline $20-25$ & 20 & $71 \%$ & $86 \%$ & Sedang \\
\hline $26-27$ & 4 & $14 \%$ & $100 \%$ & Tinggi \\
\hline
\end{tabular}

Dari tabel distribusi frekuensi diatas dapat diketahui bahwa sama halnya yang terdapat dalam kelas kontrol dengan 7 nomor item yang terdapat dalam angket minat belajar peserta didik yang diberikan pada 28 peserta didik di kelas eksperimen diperoleh skor terbanyak adalah 20-25 yaitu dengan 20 peserta didik atau sekitar $71 \%$ dari total keseluruhan peserta didik dalam kelas eksperimen dan masuk kedalam kategori sedang, artinya peserta didik senang dalam proses pembelajaran, ketertarikan terhadap media pembelajaran dan bersemangat dalam pembelajaran luas daerah segitiga. Selanjutnya skor $16-19$ dan skor $26-27$ mendapatkan frekuensi yang sama yaitu 4 peserta didik atau 14\%. dari total keseluruhan peserta didik kelas eksperimen. Dengan 16 - 19 terdapat dalam kategori rendah sehingga peserta didik tersebut hanya memenuhi sekitar satu indikator minat belajar atau bahkan tidak memenuhi indikator angket minat belajar. Dan skor $26-$ 27 yang termasuk dalam kategori tinggi sehingga peserta didik memenuhi hampir semua indikator atau memenuhi semua inndikator dalam angeket minat belajar tersebut.

Dengan demikian, berdasarkan hasil analisis data yang telah dilakukan, dengan kriteria sebagai berikut:

Jika $\mathrm{t}_{\text {hitung }}<\mathrm{t}_{\text {tabel }}$ maka $\mathrm{H}_{0}$ ditolak dan $\mathrm{H}_{\alpha}$ diterima.

Jika $\mathrm{t}_{\text {hitung }} \leq \mathrm{t}_{\text {tabel }}$ maka $\mathrm{H}_{0}$ diterima dan $\mathrm{H}_{\alpha}$ ditolak. 
2766 Efektivitas Media Powerpoint dalam Pembelajaran Materi Luas Daerah Segitiga untuk Meningkatkan Minat Belajar Peserta Didik di Sekolah Dasar - Fikri Alamsyah Nugraha, Epon Nur'aeni, Yusuf Suryana,

Muhammad Rijal Wahid M

DOI: https://doi.org/10.31004/edukatif.v3i5.931

Dengan menghasilkan data sebagai berikut:

Tabel 5. Efektivitas Hasil Penelitian Pembelajaran Luas Daerah Segitiga dengan Menggunakan Media Pembelajaran Powerpoint dalam Minat Belajar Peserta Didik Kelas IV (Uji-T)

\begin{tabular}{|c|c|c|c|c|}
\hline Kelas & Rata-Rata & St.dev & $\mathbf{T}_{\text {hitung }}$ & $\mathbf{T}_{\text {tabel }}$ \\
\hline Eksperimen & 22,25 & 2,78 & \multirow{2}{*}{2,14} & \multirow{2}{*}{1,673} \\
\hline Kontrol & 19,50 & 2,15 & & \\
\hline
\end{tabular}

Berdasarkan tebal 5 diatas, jika $t_{\text {hitung }}$ sudah didapatkan, selanjutnya dibandingan dengan $t_{\text {tabel }}$ yang diambil dari tabel distribusi $t$ dengan perhitungan dk sebagai berikut:

$d k=n_{1}+n_{2}-2=d k=28+28-2=\mathbf{5 4}$

$d k$ dihasilkan 54 dengan artian besar $t_{\text {tabel }}$ dengan probabilitas 1 skor dan taraf signifikan $5 \%=0,05$ adalah 1,67356 .

Dengan demikian, $t_{\text {hitung }}=2,141$ dan $t_{\text {tabel }}=1,673$, melihat kriteria pengambilan keputusan $\mathrm{H}_{0}$

ditolak karena $t_{\text {hitung }}>t_{\text {tabel }}=2,141>1,673$ dan $\mathrm{H}_{\mathrm{a}}$ dapat disimpulkan bahwa penggunaan media powerpoint terbukti efektif dalam pembelajaran materi luas daerah segitiga untuk meningkatkan minat belajar peserta didik Kelas IV Sekolah Dasar.

Dengan menggunakan media powerpoint dapat membantu guru menyampaikan materi luas daerah segitiga dengan mudah dan dapat diterima dengan baik oleh peserta didik, sehingga dapat meningkatkan hasil belajarnya dengan optimal. Hal ini sesuai dengan penelitian (Elpira \& Ghufron, 2015) bahwa media powerpoint memberikan pengaruh terhadap minat belajar peserta didik dalam pembelajaran dapat dilihat setelah penggunaan media powerpoint adanya peningkatan baik dari segi minat ataupun hasil pembelajaran. Dalam hal ini guru dituntut untuk bisa memanfaatkan beragam media dengan mengikuti perkembangan jaman agar menciptakan pembelajaran yang menarik dan menciptakan suasana pembelajaran yang semakin dinamis. Hal ini sesuai dengan yang disampaikan oleh (Miarso, 2016) (2009, hlm. 459) bahwa Media membangkitkan keinginan dan minat baru. Dengan menggunakan media pendidikan, horizon pengalaman anak semakin luas, persepsi semakin tajam, konsep-konsep dengan sendirinya semakin lengkap. Akibatnya keinginan dan minat untuk belajar selalu muncul.

Dalam penggunaan media powerpoint, masih banyak guru yang belum memanfaatkan media tersebut. Padahal media powerpoint memberikan kemudahan untuk guru serta peserta didik dalam mencapai tujuan pembelajarannya. Menurut hasil wawancara guru menuturkan bahwa dalam penggunaan media powerpoint itu belum lebih baik dari metode ceramah yang sudah digunakannya sejak dulu. Seyogyanya penggunaan media pada jaman sekarang ini sangat mempunyai keterhubungan dengan peserta didik. Melihat peserta didik yang sudah paham akan teknologi di jaman sekarang, guru pun perlu menambah keterampilan mereka salah satunya dalam penggunaan media pembelajaran yang mengandung teknologi. Oleh karena itu, pembelajaran yang menarik pasti dapat meningkatkan minat belajar peserta didik sehingga penggunaaan media pada materi yang akan disampaikan dan mengandung teknologi maka akan meningkatkan minat belajar peserta didik.

\section{KESIMPULAN}

Berdasarkan hasil penelitian yang dilakukan untuk meningkatkan minat belajar peserta didik kelas IV yang dilaksanakan di SDN 1 Sukamaju menunjukan efektivitas dalam penggunaan media powerpoint dalam materi luas daerah segitiga, karena dibuktikan dengan hasil skor angket bahwa kelas eksperimen yang diberikan perlakuan media powerpoint menunjukan skor yang lebih tinggi daripada kelas kontrol yang tidak diberikan perlakuan media powerpoint. Berdasarkan hasil analisis angket minat belajar peserta didik, 
2767 Efektivitas Media Powerpoint dalam Pembelajaran Materi Luas Daerah Segitiga untuk Meningkatkan Minat Belajar Peserta Didik di Sekolah Dasar - Fikri Alamsyah Nugraha, Epon Nur'aeni, Yusuf Suryana,

Muhammad Rijal Wahid M

DOI: https://doi.org/10.31004/edukatif.v3i5.931

menghasilkan temuan bahwa peserta didik lebih bersemangat dalam pembelajaran luas daerah segitiga dengan menggunakan media powerpoint.

\section{DAFTAR PUSTAKA}

Annisa, N., \& Simbolon, N. (2018). Pengembangan Media Pembelajaran Interaktif Ipa Berbasis Model Pembelajaran Guided Inquiry Pada Materi Gaya Di Kelas Iv Sd Negeri 101776 Sampali. School Education Journal Pgsd Fip Unimed, 8(2), 217-229. Https://Doi.Org/10.24114/Sejpgsd.V8i2.10199

Asnawir, B. U. (2002). Media Pembelajaran. Ciputat Pers.

Basa, Z. A., \& Hudaidah. (2021). Perkembangan Pembelajaran Daring Terhadap Minat Belajar Matematika Siswa SMP Pada Masa Pandemi Covid-19. Edukatif: Jurnal Ilmu Pendidikanjurnal Ilmu Pendidikan, 3(3), 943-950.

Chou, P. N., Chang, C. C., \& Lu, P. F. (2015). Prezi Versus Powerpoint: The Effects Of Varied Digital Presentation Tools On Students' Learning Performance. Computers And Education, 91, 73-82. Https://Doi.Org/10.1016/J.Compedu.2015.10.020

Chrismawati, M., Septiana, I., \& Purbiyanti, E. D. (2021). Peningkatan Hasil Belajar Melalui Model Flipped Classroom Berbantuan Media Power Point Dan Audio Visual Di Sekolah Dasar Mirna. Edukatif: Jurnal Ilmu Pendidikan, 3(5), 1928-2934.

Elpira, N., \& Ghufron, A. (2015). Pengaruh Penggunaan Media Powerpoint Terhadap Minat Dan Hasil Belajar Ipa Siswa Kelas Iv Sd. Jurnal Inovasi Teknologi Pendidikan, 2(1), 94-104. Https://Doi.Org/10.21831/Tp.V2i1.5207

Fauziah, A., Rosnaningsih, A., \& Azhar, S. (2017). Hubungan Antara Motivasi Belajar Dengan Minat Belajar Siswa Kelas Iv Sdn Poris Gaga 05 Kota Tangerang. Jurnal JPSD (Jurnal Pendidikan Sekolah Dasar), 4(1), 47. Https://Doi.Org/10.26555/Jpsd.V4i1.A9594

Flora Siagian, R. E. (2015). Pengaruh Minat Dan Kebiasaan Belajar Siswa Terhadap Prestasi Belajar Matematika. Formatif: Jurnal Ilmiah Pendidikan MIPA, 2(2), 122-131. Https://Doi.Org/10.30998/Formatif.V2i2.93

Harahap, H. S., Hrp, N. A., Nasution, I. B., Harahap, A., Harahap, A., \& Harahap, A. (2021). Hubungan Motivasi Berprestasi, Minat Dan Perhatian Orang Tua Terhadap Kemandirian Siswa. Edukatif: Jurnal Ilmu Pendidikan, 3(4), 1133-1143. Https://Edukatif.Org/Index.Php/Edukatif/Index

Lestari, E. K., \& Yudhanegara, R. M. (2017). Penelitian Pendidikan Matematika. Refika Adhitama.

Lestari, I. (2013). Pengaruh Waktu Belajar Dan Minat Belajar Terhadap Hasil Belajar Matematika. Formatif: Jurnal Ilmiah Pendidikan MIPA, 3(2), 115-125. Https://Doi.Org/10.30998/Formatif.V3i2.118

Miarso, Y. (2016). Menyemai Benih Teknologi Pendidikan (8 Ed.). KENCANA.

Mufti, N. N., Pranata, O. H., \& Muharram, M. R. W. (2020). Studi Literatur: Tangram Sebagai Media Pembelajaran Geometri Nasisah. (JKPD) Jurnal Kajian Pendidikan Dasar, 5(2), 93-99.

Mustajin, A., L, E. N., \& Nugraha, A. (2019). Peningkatan Pemahaman Konsep Rumus Luas Daerah Segitiga Menggunakan Multimedia Interaktif. Indonesian Journal Of Primary Education Peningkatan, 3(1), 101108. Https://Doi.Org/10.17509/Ijpe.V3i1.18602

Nuraeni, E, L \& Rijal, M, W, M. (2017). Konsep Dasar Geometri. UPI Kampus Tasikmalaya.

Nurseto, T. (2012). Membuat Media Pembelajaran Yang Menarik. Jurnal Ekonomi Dan Pendidikan, 8(1), 1935. Https://Doi.Org/10.21831/Jep.V8i1.706

Puspita, A. M. I., Puspitaningsih, F., \& Diana, K. Y. (2020). Keefektifan Media Pembelajaran Powerpoint Interaktif Untuk Meningkatkan Hasil Belajar Siswa Sekolah Dasar. TANGGAP: Jurnal Riset Dan 
2768 Efektivitas Media Powerpoint dalam Pembelajaran Materi Luas Daerah Segitiga untuk Meningkatkan Minat Belajar Peserta Didik di Sekolah Dasar - Fikri Alamsyah Nugraha, Epon Nur'aeni, Yusuf Suryana,

Muhammad Rijal Wahid M

DOI: https://doi.org/10.31004/edukatif.v3i5.931

Inovasi Pendidikan Dasar, 1(1), 49-54.

Roblyer, M. D., \& Doering, A. H. (2014). Integrating Educational Technology Into Teaching (6th Ed.). Harlow, Essex : Pearson.

Sirait, E. D. (2016). Pengaruh Minat Belajar Terhadap Prestasi Belajar Matematika. Jurnal Formatif, 6(1), $35-43$.

Yunitasari, R., \& Hanifah, U. (2020). Pengaruh Pembelajaran Daring Terhadap Minat Belajar Siswa Pada Masa COVID 19. Edukatif: Jurnal Ilmu Pendidikan, 2(3), 232-243. Https://Doi.Org/10.31004/Edukatif.V2i3.142

Yuza, A. (2018). Pembelajaran Luas Daerah Bangun Datar Di Sekolah Dasar. MENARA Ilmu, XII(8), 7-16. 